\title{
Strategy to Develop Traditional Fishery Business in Implementing the Principle of Sustainable Business
}

\author{
Helvi Yanfika ${ }^{*}$, Siti Amanah², Anna Fatchiya², Pang S.Asngari² \\ ${ }^{1}$ Faculty of Agriculture, University of Lampung \\ ${ }^{2}$ Department of Communication Science and Community Development, \\ Faculty of Human Ecology, Bogor Agricultural University
}

\begin{abstract}
The importance of sustainable development in fishery has been clearly seen in Indonesia through the existence of Law No.31 Year 2004 on Fishery. It is stated that fishery development is aimed to create job opportunities, fish farmer and fisherman welfare, and to maintain the sustainability of fishery resource and environment. Therefore, all aspects of fishery development activities, including traditional fish processing business should be based on the view of sustainable development. According to the description, the objectives of this study are: (1) to analyze traditional fish processing business; (2) to determine factors influencing one another in sustainable fishery business; and (3) to formulate strategy to improve the competence of traditional processing workers. This research was conducted through the method of survey in three regencies in Lampung Province; namely Tanggamus Regency, Pringsewu Regency, and East Lampung Regency, with a number of samples amounting to 235 respondents; later on the number of samples in each group was determined using the technique of proportional random sampling. Assessment towards the fish processing workers in sustainable traditional processing business generated quite good result since the processing workers were confident that the business developed well and sustainably. The competence of processing workers is influenced by non-formal education and entrepreneurial characteristics. The competence and implementation of extension has a direct influence, while individual characteristics of processing workers indirectly influence the sustainable traditional fishery business. Strategy to improve the competence of sustainable traditional fishery business is done by: (a) strengthening the competence of traditional fish processing workers particularly in technical and managerial aspects through the development of entrepreneurial characteristics; and (b) strengthening the extension intensity through extension method and media to create changes in behavior in running a sustainable traditional fishery business (economy, social, and environment).
\end{abstract}

Keywords: Sustainable, fishery, traditional processing workers, strategy

\section{Introduction}

The demand for animal source food consumption, particularly fish, is quite high (53.9 percent) - Food Security 2015. This condition shows that fish is still the main animal protein source in Indonesian society. Fish is the source of unsaturated fatty acid, taurine, and omega-3 fatty acid which are good for human body, thus most people consider to increase their protein consumption from fish. Compared to livestock meat, fish has higher nutrient (Ciptanto 2010). Concerning the important role of fish source food for the quality of human resource, sufficient availability of fish to be consumed is required. Therefore, the strategy of fish processing business should consider economic, social, and environmental aspects to be sustainable.

The marine area of $24,820 \mathrm{~km}^{2}$ in Lampung Province has placed Lampung as the province with great resources of marine and fishery. The field of fish product processing, especially traditional processing, should be developed and gain special attention. About
60 percent of current fish catches are marketed in raw condition, 35 percent are traditionally processed, and 5 percent are processed in a modern way (Dinas Kelautan dan Perikanan Provinsi Lampung, 2016).

Several researches showed that there were problems faced in fish product processing that has been done traditionally; starting from the use of raw material availability, technology, facility and infrastructure, as well as the processing of raw material (Yuliana et al. 2011; Riyadi et al.2012; Devi et al. 2016), related to the processing product which is not safe for consumption.

Concerning this condition, the competence of traditional fish processing workers should be improved to produce processed product with high quality. The importance of sustainable fishery development has been clearly visible in Indonesia through the existence of Law No. 31 Year 2004 on Fishery. It is stated that fishery management is aimed to create job opportunity, ensure the welfare of fish farmer and fisherman, as well as maintain the sustainability of fishery resource and environment.

\footnotetext{
${ }^{1}$ Korespondensi penulis

E-mail: helviyanfika@yahoo.co.id
} 
Hence, all aspects of fishery development activities, including the traditional fishery should be based on the view of sustainable development.

According to Sukadi (2008), sustainable development is oriented not only to production increase, but also to the impact of aquaculture business on the sustainability of surrounding environment, and the demand for product quality and safety by consumers and applicable rules. Therefore, improvement in technology and management system are directed to the environmentally-friendly production process which also consider food safety. Basically, sustainable development activities implements the principles of sustainable fishery which includes the main aspects of ecology, social, and economy.

Competence, according to Spencer and Spencer (1993), is the form of motive, attitude, skill, knowledge, behavior, or other individual characteristics which are important to perform a job. Based on Helmi (2003), Sapat et al (2012), Grudzinskiy et al. (2015), and Hladik \& Jadama (2015), competence is a factor which is able to affect the result achieved by a person, and having good competence means that sustainable fishery business will be realized. Based on the description, this study is aimed: (1) to analyze traditional fish processing business (2) to determine factors influencing one another in sustainable fishery business; and (3) to formulate strategy to improve the competence of traditional processing workers.

\section{Research Methods}

This study was done using the method of survey in three regencies in Lampung Province, namely; Tanggamus Regency, Pringsewu Regency, and East
Lampung Regency. The population was traditional fish processing workers (salting, smoking, brining, and fermenting) amounting to 570 workers. The number of samples which was determined using the formula of Slovin with error level of 5 percent resulted in 235 respondents. Furthermore, the number of samples in each group was determined using the technique of proportional random sampling (Table 1).

Analysis of the effects of independent variables on the dependent variable was done through the Structural Equation Modeling (SEM) for internal characteristics of processing workers $\left(\mathrm{X}_{1}\right)$, extension $\left(\mathrm{X}_{2}\right)$, institutional support $\left(\mathrm{X}_{3}\right)$, processing worker competence $\left(\mathrm{Y}_{1}\right)$, and sustainable fishery business $\left(\mathrm{Y}_{2}\right)$. The field data collection was done during July-September 2017.

\section{Results and Discussion}

\section{Individual Characteristics}

Internal characteristics of traditional processing workers include age, formal education, non-formal education, business experience, motivation, entrepreneurial characteristics, business turnover, number of labor, and perception on food security.

Table 2 shows that the age of processing workers is mostly in the range of young age. Formal education completed by the workers is elementary-junior high (SD-SMP), while non-formal education attended is still limited. Yet, their experience in performing the business has been long enough; thus it becomes their basic capital in doing the function and task, and the processing workers also has good motivation and entrepreneurial characters. This condition also becomes their capital in performing the business well; thus the

Table 1. Total of Population and Samples of Traditional Fish Processing Workers

\section{Type of activity}

\begin{tabular}{|c|c|c|c|c|c|c|c|c|c|c|}
\hline \multirow{3}{*}{ Regency } & \multirow{2}{*}{\multicolumn{2}{|c|}{$\begin{array}{c}\text { Salting } \\
\text { (person) }\end{array}$}} & \multirow{2}{*}{\multicolumn{2}{|c|}{$\begin{array}{l}\text { Smoking } \\
\text { (person) }\end{array}$}} & \multirow{2}{*}{\multicolumn{2}{|c|}{$\begin{array}{l}\text { Brining } \\
\text { (person) }\end{array}$}} & \multirow{2}{*}{\multicolumn{2}{|c|}{$\begin{array}{c}\text { Fermenting } \\
\text { (person) }\end{array}$}} & \multirow{2}{*}{\multicolumn{2}{|c|}{$\begin{array}{l}\text { Total Number } \\
\text { (person) }\end{array}$}} \\
\hline & & & & & & & & & & \\
\hline & $\mathbf{N}$ & $\mathrm{n}$ & $\mathbf{N}$ & $\mathbf{N}$ & $\mathbf{N}$ & $n$ & $\mathbf{N}$ & n & $\mathbf{N}$ & $\mathbf{N}$ \\
\hline Tanggamus & 53 & 22 & 29 & 12 & 46 & 19 & 15 & 6 & 143 & 59 \\
\hline Pringsewu & 0 & 0 & 2 & 1 & 131 & 54 & 0 & 0 & 133 & 55 \\
\hline East Lampung & 216 & 89 & 10 & 4 & 15 & 6 & 53 & 22 & 294 & 121 \\
\hline Total & 269 & 111 & 41 & 17 & 192 & 79 & 68 & 28 & 570 & 235 \\
\hline
\end{tabular}


Table 2. Characteristics of Traditional Fish Processing Workers

\begin{tabular}{|c|c|c|c|c|}
\hline \multirow{2}{*}{ No } & \multirow{2}{*}{ Indicator } & \multirow{2}{*}{ Category } & \multicolumn{2}{|c|}{ Number of Respondent } \\
\hline & & & (Person) & $\%$ \\
\hline \multirow[t]{4}{*}{1.} & Age (Years) & Young (20-33.7) & 41 & 17,4 \\
\hline & & Early Adult (33.8 - 40.5) & 70 & 29,8 \\
\hline & & Adult $(40.6-59.3)$ & 75 & 32,0 \\
\hline & & Old $(59.4-72)$ & 49 & 20,8 \\
\hline \multirow[t]{4}{*}{2.} & Formal education & Elementary (SD) & 125 & 53,2 \\
\hline & & Junior High (SMP) & 64 & 27,2 \\
\hline & & Senior High (SMA) & 45 & 19,1 \\
\hline & & Higher Education (D3/S1) & 1 & 0,4 \\
\hline \multirow[t]{3}{*}{3.} & Non-formal education & Never & 181 & 77,0 \\
\hline & & Seldom (1-2 times) & 49 & 20,9 \\
\hline & & Often (3-4 times) & 5 & 2,1 \\
\hline \multirow[t]{4}{*}{4.} & Experience & Very low (1-3 years) & 0 & 0 \\
\hline & & Low (>3- 5 years) & 3 & 1,3 \\
\hline & & $\operatorname{High}(>5-10$ years $)$ & 55 & 23,4 \\
\hline & & Very high ( $>10$ years) & 177 & 75,3 \\
\hline \multirow[t]{4}{*}{5.} & Motivation & Very low $(0-25)$ & 2 & 0,9 \\
\hline & & Low $(25.1-50)$ & 39 & 16,6 \\
\hline & & $\operatorname{High}(50.1-75)$ & 117 & 49,8 \\
\hline & & Very high $(75.1-100)$ & 77 & 32,8 \\
\hline \multirow[t]{4}{*}{6.} & Entrepreneurial Characteristic & Very low $(0-25)$ & 26 & 11,1 \\
\hline & & Low $(25.1-50)$ & 111 & 47,2 \\
\hline & & $\operatorname{High}(50.1-75)$ & 98 & 41,7 \\
\hline & & Very high $(75.1-100)$ & 0 & 0 \\
\hline \multirow[t]{4}{*}{7.} & Turnover & Very low (<50 million) & 9 & 3,8 \\
\hline & & Low (50 m-500 million) & 196 & 83,4 \\
\hline & & High (500 m - 1 billion) & 23 & 9,8 \\
\hline & & Very high ( $>1$ billion) & 7 & 3,0 \\
\hline \multirow[t]{4}{*}{8.} & Labor & Very low (1-5 labor) & 151 & 64,3 \\
\hline & & Low (6 -10 labor) & 69 & 29,4 \\
\hline & & High (10 -15) & 15 & 6,4 \\
\hline & & Very high $(>15)$ & 0 & 0 \\
\hline \multirow[t]{4}{*}{9.} & Perception & Very low $(0-25)$ & 1 & 0,4 \\
\hline & & Low $(25.1-50)$ & 75 & 31,9 \\
\hline & & $\operatorname{High}(50.1-75)$ & 159 & 67,7 \\
\hline & & Very high $(75.1-100)$ & 1 & 0,4 \\
\hline
\end{tabular}

turnover obtained increases from current condition which is still considered low. Traditional processing business is also included in a small-scale business regarding the number of labor which is relatively small (1-5 people). Moreover, perception of processing workers on product that is safe to consume has been considered excellent; thus it supports the processing workers to produce product with high quality.

\section{Extension}

The implementation of extension should be improved since the method, media, and material offered are considered not suitable, as can be seen from the assessment of processing workers, which mostly put it into low category. The extension performed all the time is still categorized as top down, which becomes one of 
the causes why current extension has not yet changed the behavior and capability/competence of traditional processing workers in performing business. However, this result is not in line with several opinions (Amanah 2005; Fatchiya 2010; Helmy 2013; Yuliana et $a$, 2011; Sapar et al,. 2012) which say that the extension received by workers is infrequent, not continuous, and only in accordance with the government program.

Table 3. Implementation of Extension in Traditional Fish Processing Workers

\begin{tabular}{|c|c|c|c|c|}
\hline \multirow[t]{2}{*}{ No } & \multirow[t]{2}{*}{ Indicator } & \multirow[t]{2}{*}{ Category } & \multicolumn{2}{|c|}{$\begin{array}{l}\text { Number of } \\
\text { Respondent }\end{array}$} \\
\hline & & & (Person) & $\%$ \\
\hline \multirow[t]{4}{*}{1.} & \multirow[t]{4}{*}{ Method } & $\begin{array}{l}\text { Very low (0- } \\
25)\end{array}$ & 6 & 2,6 \\
\hline & & Low (25.1-50) & 229 & 97,4 \\
\hline & & High (50.1-75) & 0 & 0 \\
\hline & & $\begin{array}{l}\text { Very high } \\
(75.1-100)\end{array}$ & 0 & 0 \\
\hline \multirow[t]{4}{*}{2.} & \multirow[t]{4}{*}{ Media } & $\begin{array}{l}\text { Very low (0- } \\
25)\end{array}$ & 57 & 24,3 \\
\hline & & Low (25.1-50) & 178 & 75,7 \\
\hline & & High (50.1-75) & 0 & 0 \\
\hline & & $\begin{array}{l}\text { Very high } \\
(75.1-100)\end{array}$ & 0 & 0 \\
\hline \multirow[t]{4}{*}{3.} & \multirow[t]{4}{*}{ Material } & $\begin{array}{l}\text { Very low (0- } \\
25)\end{array}$ & 1 & 0,4 \\
\hline & & Low (25.1-50) & 187 & 79,6 \\
\hline & & High (50.1-75) & 47 & 20,0 \\
\hline & & $\begin{array}{l}\text { Very high } \\
(75.1-100)\end{array}$ & 0 & 0 \\
\hline \multirow[t]{4}{*}{4.} & \multirow[t]{4}{*}{ Capability } & $\begin{array}{l}\text { Very low (0- } \\
25)\end{array}$ & 5 & 2,1 \\
\hline & & Low (25.1-50) & 13 & 5,5 \\
\hline & & High (50.1-75) & 99 & 42,1 \\
\hline & & $\begin{array}{l}\text { Very high } \\
(75.1-100)\end{array}$ & 118 & 50,2 \\
\hline
\end{tabular}

\section{Institutional Support}

Table 4 indicates that the access for capital and support of facility is still limited as seen from the assessment of processing workers which is in the category of low. Processing workers assess that it is still difficult to obtain the capital from financial institution.

\section{Competence of Processing Worker}

Technical and managerial competence is included in
Table 4. Institutional Support for Traditional Fishery Business

\begin{tabular}{|c|c|c|c|c|}
\hline \multirow[t]{2}{*}{ No } & \multirow{2}{*}{ Indicator } & \multirow{2}{*}{ Category } & \multicolumn{2}{|c|}{$\begin{array}{c}\text { Number } \\
\text { of Respondent }\end{array}$} \\
\hline & & & (Person) & $\%$ \\
\hline \multirow[t]{4}{*}{1.} & \multirow[t]{4}{*}{ Capital } & Very low $(0-25)$ & 234 & 99.6 \\
\hline & & Low (25.1-50) & 1 & 0.4 \\
\hline & & $\operatorname{High}(50.1-75)$ & 0 & 0 \\
\hline & & $\begin{array}{l}\text { Very high } \\
(75.1-100)\end{array}$ & 0 & 0 \\
\hline \multirow[t]{4}{*}{2.} & \multirow{4}{*}{$\begin{array}{l}\text { Production } \\
\text { facility }\end{array}$} & Very low (0-25) & 52 & 22.1 \\
\hline & & Low $(25.1-50)$ & 89 & 37.9 \\
\hline & & $\operatorname{High}(50.1-75)$ & 94 & 40.0 \\
\hline & & $\begin{array}{l}\text { Very high } \\
(75.1-100)\end{array}$ & 0 & 0 \\
\hline \multirow[t]{4}{*}{3.} & \multirow[t]{4}{*}{ Market } & Very low (0-25) & 2 & 0.9 \\
\hline & & Low (25.1-50) & 39 & 16.6 \\
\hline & & High (50.1-75) & 117 & 49.8 \\
\hline & & $\begin{array}{l}\text { Very high } \\
(75.1-100)\end{array}$ & 77 & 32.8 \\
\hline \multirow[t]{2}{*}{4.} & \multirow{2}{*}{$\begin{array}{l}\text { Group of } \\
\text { processing } \\
\text { worker }\end{array}$} & Very low $(0-25)$ & 5 & 2.1 \\
\hline & & Low (25.1-50) & 13 & 5.5 \\
\hline \multirow[t]{4}{*}{5.} & \multirow{4}{*}{$\begin{array}{l}\text { Higher } \\
\text { education }\end{array}$} & Very low (0-25) & 87 & 37.0 \\
\hline & & Low $(25.1-50)$ & 134 & 57.0 \\
\hline & & High (50.1-75) & 7 & 3.0 \\
\hline & & $\begin{array}{l}\text { Very high } \\
(75.1-100)\end{array}$ & 7 & 3.0 \\
\hline \multirow[t]{4}{*}{6.} & \multirow{4}{*}{$\begin{array}{l}\text { Business } \\
\text { partner }\end{array}$} & Very low (0-25) & 5 & 2.1 \\
\hline & & Low (25.1-50) & 13 & 5.5 \\
\hline & & High (50.1-75) & 99 & 42.1 \\
\hline & & $\begin{array}{l}\text { Very high } \\
(75.1-100)\end{array}$ & 118 & 50.2 \\
\hline
\end{tabular}

low category, while social competence is considered good (Table 5). This finding shows that the traditional processing workers still require support from the related institution to improve their competence, particularly in technical and managerial aspects of fish processing. However, current condition reveals that those aspects have not yet been optimally done; thus both of the two competences are still limited.

\section{Technical Competence}

The respondents' technical competence shows low value according to several indicators (Table 6). Most all fish processing workers have separated fish 
according to the size and species, and they do not use illegal food additives, yet some of processing workers use flavoring like turmeric, lemongrass, and bay leaf, particularly the processing workers of mackerel brining in Pringsewu Regency. This activity is performed to produce better aroma and more tasty fish, while some of traditional fish processing workers only use salt. The result of observation shows that most fish processing locations are far from pollution source, close to clean water supply, equipped with sewage system, and the business location is easy to reach.

Table 5. Technical Competence of Traditional Fish Processing Workers

\begin{tabular}{|c|c|c|c|c|}
\hline \multirow[t]{2}{*}{ No } & \multirow{2}{*}{ Variable } & \multirow{2}{*}{ Category } & \multicolumn{2}{|c|}{$\begin{array}{l}\text { Number of } \\
\text { Respondent }\end{array}$} \\
\hline & & & (Person) & $\%$ \\
\hline \multirow[t]{4}{*}{1} & \multirow{4}{*}{$\begin{array}{l}\text { Technical } \\
\text { Competence }\end{array}$} & Vey low (0-25) & 23 & 9,8 \\
\hline & & Low (25.1-50) & 211 & 89,8 \\
\hline & & $\begin{array}{l}\text { High } \\
(50.1-75)\end{array}$ & 1 & 0,4 \\
\hline & & $\begin{array}{l}\text { Very high } \\
(75.1-100)\end{array}$ & 0 & 0 \\
\hline \multirow[t]{4}{*}{2} & \multirow{4}{*}{$\begin{array}{l}\text { Managerial } \\
\text { Competence }\end{array}$} & Vey low $(0-25)$ & 33 & 14,0 \\
\hline & & $\begin{array}{l}\text { Low } \\
(25.1-50)\end{array}$ & 173 & 73,2 \\
\hline & & High (50.1-75) & 30 & 12,8 \\
\hline & & $\begin{array}{l}\text { Very high } \\
(75.1-100)\end{array}$ & 0 & 0 \\
\hline \multirow[t]{4}{*}{3} & \multirow{4}{*}{$\begin{array}{l}\text { Social } \\
\text { Competence }\end{array}$} & Vey low $(0-25)$ & 0 & 0 \\
\hline & & $\begin{array}{l}\text { Low } \\
(25.1-50)\end{array}$ & 74 & 31,5 \\
\hline & & High (50.1-75) & 147 & 62,6 \\
\hline & & $\begin{array}{l}\text { Very high } \\
(75.1-100)\end{array}$ & 14 & 6,0 \\
\hline
\end{tabular}

The business building is easy to clean, yet most of it is not separated from the residence, and although the building has bright lighting, it tends to be dark. Traditional fish processing workers have used tools and equipment which are not easy to rust, do not absorb water, and are easy to clean such as several tools and equipment made of aluminium. Moreover, some processing workers also have arranged and organized their tools and equipment well, yet there are also processing workers who do not organize their tools, and not all workers separate the tools and equipment used for production, waste and additional material.
In the process of packaging and labeling, most of all processing workers still use candle light to seal the package instead of packaging machine, and they also do not put label inside the package.

Table 6. Distribution of processing worker based on the technical competence of traditional fish processing worker

\begin{tabular}{|c|c|c|c|c|c|}
\hline \multirow{3}{*}{ No } & \multirow{3}{*}{ Technical competence } & \multicolumn{4}{|c|}{ Category } \\
\hline & & $\begin{array}{l}\text { Very } \\
\text { low }\end{array}$ & Low & High & $\begin{array}{l}\text { Very } \\
\text { high }\end{array}$ \\
\hline & & $\%$ & $\%$ & $\%$ & $\%$ \\
\hline \multirow{4}{*}{$\begin{array}{l}1 \\
2\end{array}$} & $\begin{array}{l}\text { Selection and determi- } \\
\text { nation of raw material }\end{array}$ & 0 & 5,1 & 94,9 & 0 \\
\hline & Additional material & & & & \\
\hline & $\begin{array}{l}\text { a. use legal food ad- } \\
\text { ditive }\end{array}$ & 0 & 1,7 & 98,3 & 27,2 \\
\hline & b. use flavoring & 9,8 & 47,2 & 15,7 & 0 \\
\hline \multirow[t]{8}{*}{3} & Location and building & & & & \\
\hline & $\begin{array}{l}\text { a. location is not pol- } \\
\text { luted }\end{array}$ & 9,4 & 90,2 & 0,4 & 0 \\
\hline & $\begin{array}{l}\text { b. location is close to } \\
\text { clean water supply }\end{array}$ & 13,2 & 86,4 & 0,4 & 0 \\
\hline & $\begin{array}{l}\text { c. location has sewage } \\
\text { system }\end{array}$ & 11,5 & 88,1 & 0,4 & 0 \\
\hline & $\begin{array}{l}\text { d. location is easy to } \\
\text { reach }\end{array}$ & 3,4 & 96,2 & 0,4 & 0 \\
\hline & $\begin{array}{l}\text { e. the building is easy } \\
\text { to clean }\end{array}$ & 6,8 & 48,5 & 44,7 & 0 \\
\hline & $\begin{array}{l}\text { f. the building is sepa- } \\
\text { rated from residence }\end{array}$ & 48,9 & 49,4 & 1,7 & 0 \\
\hline & $\begin{array}{l}\text { g. the building has } \\
\text { enough lighting }\end{array}$ & 46,0 & 37,9 & 16,2 & 0 \\
\hline \multirow[t]{4}{*}{4} & $\begin{array}{l}\text { Tool and equipment } \\
\text { a. tools and equipment }\end{array}$ & 0 & 0 & 0 & 0,4 \\
\hline & $\begin{array}{l}\text { are not easy to rust, do } \\
\text { not absorb water, and } \\
\text { easy to clean } \\
\text { b. tools and equipment }\end{array}$ & 17,9 & 36,6 & 45,1 & 0 \\
\hline & $\begin{array}{l}\text { are arranged/organized } \\
\text { well }\end{array}$ & 6,4 & 46,0 & 47,7 & 0 \\
\hline & $\begin{array}{l}\text { c. tools and equipment } \\
\text { for production, waste, } \\
\text { and additional material } \\
\text { are separated }\end{array}$ & 5,5 & 47,2 & 47,2 & 0 \\
\hline \multirow[t]{3}{*}{5} & Sanitation & & & & \\
\hline & $\begin{array}{l}\text { a. availability of clean } \\
\text { water, odorless, color- } \\
\text { less, and meet the stan- } \\
\text { dard of drinking water } \\
\text { b. the water is from }\end{array}$ & 6,8 & 15,7 & 71,0 & 6,4 \\
\hline & $\begin{array}{l}\text { harmless source, water } \\
\text { pipeline is arranged to } \\
\text { prevent contamination } \\
\text { with dirty water }\end{array}$ & 17,4 & 81,7 & 0,8 & 0 \\
\hline \multirow[t]{4}{*}{6} & Packaging and labeling & & & & \\
\hline & $\begin{array}{l}\text { a. using packaging } \\
\text { machine }\end{array}$ & 0 & 95,7 & 4,3 & 0 \\
\hline & $\begin{array}{l}\text { b. using label inside } \\
\text { the package }\end{array}$ & 0 & 96,2 & 3,8 & 0 \\
\hline & $\begin{array}{l}\text { c. putting halal label } \\
\text { and ingredients }\end{array}$ & 0 & 98,7 & 1,3 & 0 \\
\hline \multirow[t]{3}{*}{7} & Distribution & & & & \\
\hline & $\begin{array}{l}\text { a. use transportation } \\
\text { facility which is able to } \\
\text { protect the product }\end{array}$ & 57,9 & 30,6 & 11,5 & 0 \\
\hline & $\begin{array}{l}\text { b. transportation of } \\
\text { product is not mixed }\end{array}$ & 48,5 & 10,6 & 32,3 & 8,5 \\
\hline
\end{tabular}




\section{Managerial Competence}

Managerial competence includes (1) arrangement to determine the task of labor; (2) finance; (3) production quantity; (4) product marketing; and (5) product diversification. Managerial competence of the traditional fish processing worker is in the low category since most of processing workers have not performed the function of management. Most of the traditional processing workers do not consider the capability of the prospective employees since the employers are usually their children, relatives, or neighbors. Thus the unskilled prospective employees are taught by the workers beforehand (Table 7).

Table 7. Distribution of Processing Workers Based on Managerial Competence

\begin{tabular}{|c|c|c|c|c|c|}
\hline \multirow{3}{*}{ No } & \multirow{3}{*}{$\begin{array}{l}\text { Managerial } \\
\text { Competence }\end{array}$} & \multicolumn{4}{|c|}{ Category } \\
\hline & & $\begin{array}{l}\text { Very } \\
\text { low }\end{array}$ & Low & High & $\begin{array}{l}\text { Very } \\
\text { high }\end{array}$ \\
\hline & & $\%$ & $\%$ & $\%$ & $\%$ \\
\hline 1 & $\begin{array}{l}\text { Consider the } \\
\text { capability of new } \\
\text { employee }\end{array}$ & 27,2 & 48,1 & 24,7 & c \\
\hline 2 & $\begin{array}{l}\text { Determine the task } \\
\text { given based on the } \\
\text { capability }\end{array}$ & 0 & 26,8 & 73,2 & c \\
\hline 3 & $\begin{array}{l}\text { Record the business } \\
\text { finance }\end{array}$ & 33,2 & 34,9 & 31,9 & 0 \\
\hline 4 & $\begin{array}{l}\text { Separate the business } \\
\text { money and family } \\
\text { money }\end{array}$ & 32,8 & 37,0 & 30,2 & 0 \\
\hline 5 & $\begin{array}{l}\text { Check the stock } \\
\text { of product in store } \\
\text { before production }\end{array}$ & 25,1 & 37,0 & 29,8 & 8,1 \\
\hline 6 & $\begin{array}{l}\text { Provide holiday } \\
\text { allowance (THR) }\end{array}$ & 26.8 & 43,8 & 29,4 & c \\
\hline 7 & $\begin{array}{l}\text { Check the processed } \\
\text { product before it is } \\
\text { marketed } \\
\text { Participate in a }\end{array}$ & 2,1 & 17,0 & 32,4 & 48,5 \\
\hline 8 & $\begin{array}{l}\text { bazaar to promote the } \\
\text { product }\end{array}$ & 0 & 88,1 & 11,9 & 0 \\
\hline 9 & Sell the product & 47,7 & 41,7 & 10,2 & 0,4 \\
\hline 10 & $\begin{array}{l}\text { Offer special price for } \\
\text { big sales }\end{array}$ & 11,5 & 48,1 & 37,0 & 3,4 \\
\hline 11 & $\begin{array}{l}\text { Create product in } \\
\text { various size }\end{array}$ & 3,4 & 41,3 & 19,2 & 36,2 \\
\hline
\end{tabular}

Based on Table 7, it is known that most of processing workers have not recorded the business finance regularly, and they also have not separated the money, namely between business money and family money. Before performing production, the processing workers should check the number of stock. Besides checking the number of product stock, it is important for a processing worker to check his processed product before it is marketed. Most traditional processing workers provide holiday allowance (THR) to their employees. Most processing workers infrequently, even never attend bazaar or expo to promote or sell their product. The processing workers also do not offer discount even though consumers buy in large quantity, yet there are a few processing workers who give discount.

\section{Social Competence}

Processing workers have good relationship with the surrounding environment, both with the society in general and other processing workers, by participating in gathering event held by the society. Processing workers will help one another when one is experiencing raw material shortage. If there is a processing worker who lowers the price, he will confirm it to other processing workers. They are also quite open when there are other people who want to run the same business, and they are also open to accept suggestion related to the product (Table 8).

Table 8. Distribution of Processing Workers Based on the Social Competence of Traditional Processing Workers

\begin{tabular}{|c|c|c|c|c|c|}
\hline \multirow[b]{2}{*}{ No } & \multirow[b]{2}{*}{ Social Competence } & \multicolumn{4}{|c|}{ Category (\%) } \\
\hline & & $\begin{array}{l}\text { Very } \\
\text { low }\end{array}$ & Low & High & $\begin{array}{l}\text { Very } \\
\text { high }\end{array}$ \\
\hline 1 & $\begin{array}{l}\text { Attend meeting } \\
\text { event in surrounding } \\
\text { region }\end{array}$ & 1,7 & 46,0 & 40,0 & 12,3 \\
\hline 3 & $\begin{array}{l}\text { The behavior of } \\
\text { processing worker } \\
\text { towards other } \\
\text { processing worker } \\
\text { who lower the price }\end{array}$ & 0,4 & 34,5 & 65,1 & 0,0 \\
\hline 4 & $\begin{array}{l}\text { The behavior of } \\
\text { processing worker } \\
\text { when there is new } \\
\text { competitor }\end{array}$ & 0,4 & 0,4 & 77,9 & 21,3 \\
\hline 5 & $\begin{array}{l}\text { The behavior of } \\
\text { processing worker } \\
\text { towards critics } \\
\text { or suggestion } \\
\text { regarding the } \\
\text { product }\end{array}$ & 31,1 & 3,4 & 1,3 & 64,0 \\
\hline
\end{tabular}




\section{Traditional Fish Processing Business}

The sustainability of economy consists of processing cost, product price, and profit from the traditional fish processing business which is assessed from the current situation and prediction of the future condition. Production cost at present is considered high since the price of production material is increasing. However, in the future, production cost may increase or decrease. The price of product will increase due to the scarcity of raw material, which further will affect the profit received by the traditional fish processing workers. Social sustainability of traditional fish processing workers includes the aspects of harmony, education for children, and the welfare of processing workers' family at present as well as the prediction of future condition. Sustainability of environment is related to clean water availability, also water and air pollution due to traditional fish processing activities. Table 9 shows that the processing workers think that the processing business they run continues to provide high prospect, both in the aspects of economy, social, and environment.

Table 9. Traditional Fish Processing Business

\begin{tabular}{|c|c|c|c|c|}
\hline \multirow{2}{*}{ No } & \multirow{2}{*}{ Indicator } & \multirow{2}{*}{ Category } & \multicolumn{2}{|c|}{$\begin{array}{l}\text { Number of } \\
\text { Respondent }\end{array}$} \\
\hline & & & (Person) & $\%$ \\
\hline \multirow[t]{4}{*}{1.} & Economy & $\begin{array}{l}\text { Very low } \\
(0-25)\end{array}$ & 0 & 0 \\
\hline & & Low $(25.1-50)$ & 9 & 3,8 \\
\hline & & $\begin{array}{l}\text { High } \\
(50.1-75)\end{array}$ & 167 & 71,1 \\
\hline & & $\begin{array}{l}\text { Very high } \\
(75.1-100)\end{array}$ & 59 & 25,1 \\
\hline \multirow[t]{4}{*}{2.} & Social & $\begin{array}{l}\text { Very low } \\
(0-25)\end{array}$ & 0 & 0 \\
\hline & & Low $(25.1-50)$ & 2 & 0,9 \\
\hline & & $\begin{array}{l}\text { High } \\
(50.1-75)\end{array}$ & 176 & 74,9 \\
\hline & & $\begin{array}{l}\text { Very high } \\
(75.1-100)\end{array}$ & 57 & 24,3 \\
\hline \multirow[t]{4}{*}{3.} & Environment & $\begin{array}{l}\text { Very low } \\
(0-25)\end{array}$ & 0 & 0 \\
\hline & & Low $(25.1-50)$ & 24 & 10,2 \\
\hline & & $\begin{array}{l}\text { High } \\
(50.1-75)\end{array}$ & 155 & 66,0 \\
\hline & & $\begin{array}{l}\text { Very high } \\
(75.1-100)\end{array}$ & 56 & 23,8 \\
\hline
\end{tabular}

\section{Factors Influencing the Competence}

Result of SEM analysis reveals that the competence $\left(\mathrm{Y}_{1}\right)$ is affected by individual characteristics $\left(\mathrm{X}_{1}\right)$, namely non-formal education and entrepreneurial characteristics. The regression equation is: $\mathrm{Y}_{1}=0.55+$ $0.70 ; \mathrm{R}^{2}=30 \%$.

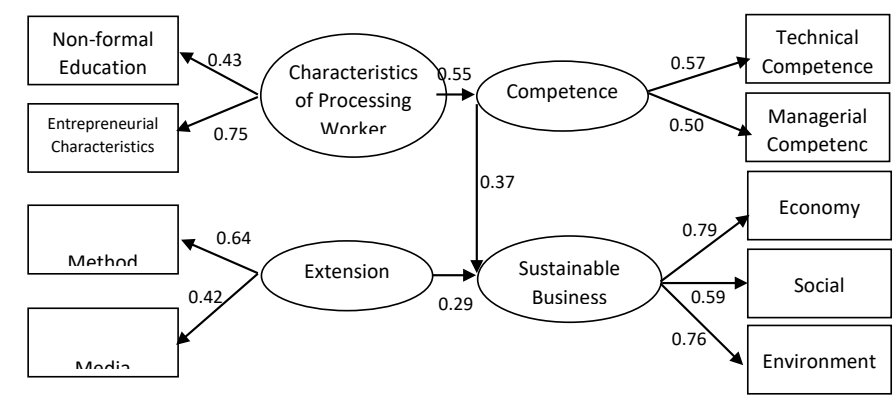

Chi Square $=46.08$, df $=23$, P-value $=0.00292$, RMSEA $=0.065$

Figure 1. SEM Model to Strengthen the Competence of Traditional Fish Processing Business Actors in Implementing the Principle of Sustainable Fishery Business

Non-formal education generates significant effects and shapes the individual characteristics in improving the competence of processing workers. The more often the processing workers participate in extension or training on fish processing business, the better the competence owned. Result of this research is in line with the research conducted by Barth et al. (2017) in Germany who stated that the key of individual competence development is obtained from non-formal education. Research conducted by Tudor (2013) in Romania showed that non-formal education such as interaction within groups, central communication, and independent studies are strategies to provide individual satisfaction in conducting activities; thus traditional processing workers, through training and group, are able to develop their capability in performing the business.

Entrepreneurial characteristic is an individual factor that should be owned by processing workers since this characteristic may influence the competence of 
processing workers in performing the sustainable fishery business. Smith \& Chimucheka (2014) mentioned that a business actor in South Africa was able to develop the economy of the country; therefore, special attention is required. Related to this condition, fish processing workers as the actors of small-scale business should develop their entrepreneurial character to support the sustainable traditional fishery business, which is in line with the result of research done by Mahadalle \& Kaplan (2017) that entrepreneurial characteristics of woman in Somalia positively affected small-scale business. Sukardi (1991) and Markum (1998) mentioned that higher entrepreneurial characteristic owned by a person means that the person has hard-working characteristics, knows the purpose of business, is able to take advantage of opportunity, is dare to take risk, and is able to adapt to new things.

\section{The Effect of Competence on Sustainable Traditional Fishery Business}

BasedonFigure 1, about $30 \%$ of sustainable fishbusiness are affected by competence $(\lambda=0.37)$ and extension $((\lambda=0.29)$. The two variables have a direct effect with regression equation: $\mathrm{Y}_{3}=0.37 \mathrm{Y}_{1}+0.29 \mathrm{X}_{2}$ $\mathrm{Y}_{3}=0.37 \mathrm{Y}_{1}+0.29 \mathrm{X}_{2}+0.70 ; \mathrm{R}^{2}=30 \%$.

Higher competence owned by processing workers, both in technique and managerial, will affect the sustainable fishery business. Technical competence is related to the production activity to create processed product with high quality, and managerial competence is associated with resources, finance, and marketing. According to Suprayitno (2011), the capability of business actors to know, to master, to comprehend, and to perform the principles of processing technique will improve the independence and success of farmers. The better the competence of a processing worker formed, the better the capability to perform the business.

Extension influences the sustainable fishery business, namely the fishery business, which is seen from the aspects of economy, social and environment. According to Amanah (2007), extension at least consists of five elements, namely: (1) learning process, (2) the existence of subjects who learn, (3) the development of awareness and the capacity of individual and group, (4) resource management for life improvement, and (5) implementation of the principle of sustainability from the aspects of social, economy, and implementation of the function of environmental sustainability.

\section{Strategy to Strengthen the Competence of Traditional Processing Business Actors in Implementing the Principle of Sustainable Fishery Business}

Managing the sustainable fishery business requires the competence of processing workers. As an actor, the quality of human resource (processing worker) is seen from his competence in performing business. Based on the result of SEM analysis (Figure 1), there are two strategies that can be applied to strengthen the competence of traditional processing business actor in implementing the principles of sustainable fishery business.

The first strategy is done by strengthening the competence of traditional fish processing workers, particularly in technical and managerial aspects by developing the entrepreneurial characteristics. Operationally, the activity to be applied is aimed to increase the frequency of non-formal education.

The second strategy is performed by strengthening the extension intensity of sustainable fishery business (economy, social and culture) through the development of market-oriented product. Thus the business generates more profit in term of economy aspect. Extension related to the society dynamics is provided in order to realize a harmony condition. Moreover, the awareness on the importance of education for the processing workers and their family is important since the fact collected from the field shows that the education level of the processing worker family ranges between elementary and junior high (SD-SMP). Thus, it is expected that the welfare of the processing workers and their family will increase along with the increase in awareness on the importance of education. Extension related to environmental sustainability is essential, for example not disposing household waste or business waste to the sea or any places to avoid pollution which will result in an impact on business. Therefore, through suitable extension method and media, such as practice/ demonstration method and interesting media, it will be easier for the processing workers to get understanding and to improve their knowledge, skill, and behavior. 


\section{Conclusion}

Assessment of processing worker towards sustainable processing business is quite good. They are confident that the business will continue to develop, generating profit in terms of economy. In terms of social life, the business creates positive impacts on the harmony, education and health aspects of processing workers' family, while the aspects of environment continues to be improved to maintain the availability of raw materials. Factors which influence one another include: (1) the competence of processing workers is affected by nonformal education and entrepreneurial characteristics; and (2) the competence and implementation of extension have a direct effect, while individual characteristics of the processing worker indirectly affect the sustainable traditional fishery business. Strategy to increase the competence of processing workers in sustainable traditional fishery business is done by: (a) strengthening the competence of traditional fish processing workers, particularly in technical and managerial aspects by developing the entrepreneurial characteristics, and (b) strengthening the extension intensity through extension method and media in order to create changes in behavior in performing the sustainable traditional fishery business (economy, social and environment).

\section{References}

Amanah S. 2005. Pengembangan masyarakat pesisir berdasarkan kearifan lokal di pesisir Kabupaten Buleleng di Provinsi Bali. [Disertasi]. Bogor (ID): Institut Pertanian Bogor.

2007. Makna Penyuluhan dan Transformasi Perilaku Manusia. Jurnal Penyuluhan. 3(1): 6366.

Amanah S. 2005. Pengembangan masyarakat pesisir berdasarkan kearifan lokal di pesisir Kabupaten Buleleng di Provinsi Bali. [Dissertation]. Bogor (ID): Institut Pertanian Bogor.

Barth M, Godemann J, Riekmann M, Stollenberg O. 2017. Developing key competencies for sustainable development in higher education. International of Sustainability in Higher Education. 8(4); 416-430.

Ciptanto S. 2010. TOP 10 Ikan Air Tawar Panduan Lengkap Pembesaran secara Organik di Kolam Air, Kolam Terpal, Karamba, dan Jala Apung.Lily Publisher. Yogyakarta.

Devi KPT Suamba IK. Artini NWP. 2016. Analisis pengendalian mutu pada pengolahan ikan palagis beku. Jurnal Agribisnis dan Agrowisata. 5(1):111.

Dinas Kelautan dan Perikanan Provinsi Lampung. 2016. Data Statistik P2HP Provinsi Lampung.

Fatchiya A. 2010. Tingkat kapasitas pembudidaya ikan dalam mengelola usaha akuakultur secara berkelanjutan. Jurnal Penyuluhan. 6(1): 67-75.

Grudzinskiy AO. Zakharova L. Bureeva N. Leonova I. Mahalin A. 2015. Personal Competences of Succession Pool for Management Positions within University Competitiveness Increase: Meaning and Identifications. Procedia Social and Behavior Science. 214(2015); 586-597.

Helmi Z, Sumardjo, Purwaningsih N, Tjitropranoto P. 2013. Hubungan kompetensi penyuluh dengan karakteristik pribadi, persepsi penyuluh terhadap dukungan kelembagaan dan persepsi penyuluh terhadap sifat inovasi cyber extension. Jurnal Agro Ekonomi. 31(1): 1-18

Hladik J, Jadama LM. 2015. Multicultural Competence of Helping Profession Students; Cross Cultural Comparison Between Europe and Africa. Procedia - Social and Behavioral Sciences. 214 (2015); 586 $-595$.

Mahadalle A, Kaplan B. 2017. Rntrepreneurial characteristic and competencies as determinat of corporate performance: a study of small enterpreneur. International Journal of Research GRATHAALAYAH. 5(5); 234-254. doi: org/10.5281/zenodo.583915.

Markum ME. 1998. Sifat sumber daya manusia Indonesia penunjang pembangunan. Disertasi Doktor. Program Pascasarjana, Fakultas Psikologi, Universitas Lampung.

Riyadi PH, Bambang AN, Agustini AW. 2015. Analisis kebijakan keamanan pangan produk hasil hasil perikanan di Pantura Jawa Tengah dan DIY.

Sapar, Jahi A, Asngari PS. Saleh A, Putupurnaba IG. 2012. Penyuluh Pertanian dan Dampaknya Pada Kompetensi Petani Kakao di Empat Wilayah Sulawesi Selatan. Jurnal Penyuluhan. 8(1);29-41.

Smith W, Chimucheka T. 2014. Entrepreneurship, economic growth and entrepreneurship theories. Mediterramean Journal of Social Science. 5(14); 160-168. doi: 10.5901/mjss.2014.v5n14p160.

Sukardi IS. 1991. Intervensi terencana faktor-faktor lingkungan terhadap pembentukkan sifat-sifat antrepreneur (Entrepreneur Traits). Disertasi 
Doktor. Program Pascasarjana, Fakultas Psikologi, Universitas Indonesia.

Suprayitno A. 2011. Model peningkatan partisipasi petani sekitar hutan dalam mengelola hutan kemiri rakyat: Kasus Pengelolaan Hutan Kemiri Kawasan Pegunungan Bulusaruang. Kabupaten Maros Sulawesi Selatan. [disertasi]. Bogor (ID): Institut Pertanian Bogor.

Spencer LM, Spencer SM. 1993. Competence At Work; Model for Superior Performance. New York (US): John Miley \& Sons. Inc.

Tudor LT. 2017. Formal non formal in formal education. Procedia Social and Behavioral Science. 76(2013); 821-826. doi : 10.1016/J.sbspro.2013.04.213.

Yuliana E. Suhardi DA. Susilo A. 2011. Timngkat penggunaan bahan kimia berbahaya pada pengolahan ikan asin. Kasus di Muara Angke dan Cilincing; Jakarta. Jurnal Pengolahan Hasil Perikanan Indonesia. XIV (1): 14-21. 